[14] Bochkarev, S., Krichkovska, L., Petrova, I., Petrov, S., Varankina, O., Belinska, A. (2017). Research of influence of technological processing parameters of protein-fat base for supply of sportsmen on activity of protease inhibitors. Technology Audit and Production Reserves, 4 (3 (36)), 27-30. doi: https://doi.org/10.15587/2312-8372.2017.108376

[15] Embaby, H. E.-S. (2010). Effect of Heat Treatments on Certain Antinutrients and in vitro Protein Digestibility of Peanut and Sesame Seeds. Food Science and Technology Research, 17 (1), 31-38. doi: https://doi.org/10.3136/fstr.17.31

[16] Kahyaoglu, T., Kaya, S. (2006). Modeling of moisture, color and texture changes in sesame seeds during the conventional roasting. Journal of Food Engineering, 75 (2), 167-177. doi: https://doi.org/10.1016/j.jfoodeng.2005.04.011

[17] Wynn, J. P., Kendrick, A., Ratledge, C. (1997). Sesamol as an inhibitor of growth and lipid metabolism in Mucor circinelloides via its action on malic enzyme. Lipids, 32 (6), 605-610. doi: https://doi.org/10.1007/s11745-997-0077-1

[18] Barry, D. S. (2007). United States Patent No. 514464. Sesamol Derivatives as Novel Inhibitors of Arachidonic Acid Formation. No. PCT/US2007/003032. Available at: https://patentimages.storage.googleapis.com/87/c6/1b/3729855488a883/ WO2007092379A2.pdf

[19] Mahendra Kumar, C., Singh, S. A. (2014). Bioactive lignans from sesame (Sesamum indicum L.): evaluation of their antioxidant and antibacterial effects for food applications. Journal of Food Science and Technology, 52 (5), 2934-2941. doi: https:// doi.org/10.1007/s13197-014-1334-6

[20] Ono, Y., Tomimori, N., Tokuda, S., Rogi, T. (2005). United States Patent No. 11794304. Sesamin/Episesamin Compositions. Washington DC US.

\title{
RESEARCH OF WHEAT DRYING IN A MICROWAVE AND COMBINED FILTER-MICROWAVE DRYER
}

\author{
Oleg Burdo \\ burdo.onaft@gmail.com \\ Igor Bezbakh \\ igorbezbakh1003@gmail.com \\ Serhii Shyshov ${ }^{l}$ \\ try2stopmeme@gmail.com \\ Aleksandr Zykov ${ }^{l}$ \\ zav380@yahoo.com \\ Igor Yarovyi ${ }^{1}$ \\ goryarov@gmail.com
}

Aleksander Gavrilov

Department of technology and equipment production and processing of livestock products Academy of bioresources and nature management «Vladimir Vernadskiy CFU»

1 Nauchnay str. Agrarnoe, Simferopol, 295492

Valentyna Bandura

Department of processes and equipment processing and food production, prof. P. S. Bernica

Vinnitsa National Agrarian University

3 Sonyachna, str., Vinnitsa, Ukraine, 21008

bandura_3@ukr.net 


\author{
Igor Mazurenko \\ Odessa State Agrarian University \\ 13 Panteleimonivska str., Odessa, Ukraine, 65000 \\ ${ }^{1}$ Department of processes, equipment, energy management \\ Odessa National Academy of Food Technologies \\ 112 Kanatna str., Odessa, Ukraine, 65010
}

\begin{abstract}
The aim of the conducted study is to determine kinetics of the complex effect of microwave energy supply and filter drying of the process of water release from the wheat layer. There is offered a combination of MW and filter drying. A special feature of this combination must be its more effectiveness and high speed of water elimination from surface layers of wet seeds and, as a result, the productivity increase of the drying way, decrease of specific energy consumption.

There was determined the influence of the specific load of the material, radiator power on processes of microwave and filter-microwave drying of wheat seeds. There were compared microwave, filter-microwave and convective drying of seeds by parameters of specific energy consumption, drying speed.

The specific energy consumption at microwave drying of seeds was $4 \mathrm{MJ} / \mathrm{kg}$, at filter-microwave drying $3.8 \mathrm{MJ} / \mathrm{kg}$ that is lower than existent convective dryers. The speed of microwave drying changes from 0,5 to $3 \% / \mathrm{min}$, filter-microwave from 0.3 to $0.7 \% / \mathrm{min}$. The speed is at the level of standard convective dryers.

The conducted studies allow to recommend a new combined way of FMW drying of seeds with low energy consumption.

Revealed features of heating and drying are possible to be used at developing industrial dryers.

The base of experimental data is possible to be used for optimizing and determining effective conditions of MW and FMW drying.

Keywords: microwave drying filter-microwave drying, wheat, drying kinetics.
\end{abstract}

DOI: $10.21303 / 2504-5695.2019 .001004$

\title{
1. Introduction
}

The process of drying is one of main methods of food products preservation. For today there are an essential number of ways and methods of drying initial raw materials and food products. Most effective drying ways are convective, conductive, infrared, microwave, sublimation, acoustic and other ones, and also their combinations.

Great attention is paid to studying combined drying methods, because their use results in increasing the driving force, decreases the time and energy consumption of the process, allows to get a high-quality product.

\section{Problem review}

A wide diapason of studies of combined drying is considered.

Combined drying processes are applied for different food products: fruits [1-3], vegetables [4-8], in chemical industry [9-13].

There are mainly used combinations of MW radiation and convective drying (CD) $[1,2]$, MW radiation and vacuum [1], infrared (IR) radiation and CD [4, 5], ultrasound and CD [6], MW, IR radiation and CD [9], discrete IR and CD [5], filter and CD [10-12].

These methods are mainly compared with convective drying. They are compared by kinetics, specific energy consumption of the process and quality of dried products (color, phenol content, vitamin $\mathrm{C}$, rehydration characteristics).

As a result, there are noted: drying speed increase at increasing MW radiation, decreasing pressure [1-3], increasing quality of a product [2, 4, 8, 13], decreasing energy consumption [5].

Filter drying is a combination of CD and air filter by the porous wet material. There are considered results of filter drying of aluminous cake [10], birch veneer in a package [11], peat and coffee slime [12]. Experimental studies of filter drying [10-12] are limited by constructions for chemical industry, variants of energy supply to the material by MW radiation are not also considered. 
In methods [1-8] there are used mainly a combination of MW or IR radiation and CD. For grain products the use of combined methods is practically not considered, the studies were conducted only for the static layer of seeds, affected by the MW field [14, 15].

Speed data of wheat seed drying are contradictory. A spread of wheat drying speed in dryers of different types is $0.5 \ldots 3 \% / \mathrm{min}$. It is connected with the diversity of varieties and properties of wheat, different initial moisture, moisture binding directly in seeds, diversity of drying methods.

Seed dryers are characterized by the high energy consumption as from $5 \mathrm{MJ} / \mathrm{kg}$ to $9 \mathrm{MJ} /$ $\mathrm{kg}$ [16] and emission of an exhausted coolant in the atmosphere. The heat content of an exhausted coolant is only by $10-15 \%$ lower than one of hot air, supplied to the drying chamber.

The condition of the process of MW wheat seed drying is characterized by an essential amount of moisture, appeared on the surface of processed particles. The presence of such surface moisture worsens conditions of the process of moisture removal and decreases its effectiveness.

It is expedient to consider a possibility of intensifying the process of moisture removal in a MW dryer for wheat seeds at the expanse of creating an intensive air flow, normal to the plane of the wet material layer with speeds, typical for filter drying methods (within 3-8 m/s), and parameters, correspondent to the normal atmosphere condition. At such organization of the moisture removal process it is possible to guarantee a high speed of moisture removal from the surface of particles and invariability (within one drying chamber) of the driving force of the process.

The aim of this study is to investigate wheat drying in microwave and combined filter-microwave dryers. A promising method of wheat seed drying may be a combination of MW and filter drying. A special feature of this combination must be its higher effectiveness and high speed of moisture removal from surface layers of particles of wet seeds and, as a result, the drying method productivity increase and the specific energy consumption decrease.

The tasks of the study:

- to determine the influence of specific load of the material, radiator power of the process of microwave drying of wheat seeds;

- to determine the influence of specific load of the material, radiator power of the process of filter-microwave drying of wheat seeds;

- to compare microwave, filter-microwave ad convective drying of seeds by parameters of specific energy consumption, drying speed.

\section{Materials and Methods}

The studies of drying were conducted on winter wheat "Podolyanka" with the initial moisture near $20 \ldots 23 \%$, that corresponds to the moisture of fresh harvested seeds. The initial moisture of seeds was determined by the digital moisture by Kett PM 600 (Kett Electric Laboratory, Japan). The thickness of the material layer remains stable $20 \mathrm{~mm}$. The initial temperature of seeds is $18 \ldots 25^{\circ} \mathrm{C}$.

For preliminary assessing the potential of the technology of microwave drying of wheat, there was conducted a series of experiments on the stand with the fixed layer of the product (Fig. 1).

The construction of the stand is microwave chamber 1 (chamber is presented without a door), with fixed electronic scales 7, measuring platform of scales on suspension 4, with fixed platform 5 of radiotransparent plastic. The distributed wheat layer is placed on platform 5 . A sample was radiated by microwave radiator 2 . The seed temperature at its processing was periodically measured by a pyrometer.

The heating chamber was ventilated by staff ventilator 3, the air speed didn't change. The radiation power $(\mathrm{N}, \mathrm{W})$ was set by staff means of control panel 6 of the chamber. For conducting a series of experiments, values $240,400,560$ and $800 \mathrm{~W}$ were selected. The material specific load $\left(\mathrm{G}, \mathrm{kg} / \mathrm{m}^{2}\right)$ on a cartridge was $5.26 ; 3.95 ; 2.63 ; 1.32 \mathrm{~kg} / \mathrm{m}^{2}$.

Before the beginning of a series of experiments the power of magnetron radiation was calorimetered by the method, accepted for microwave heating chambers. 1 liter of pure water was heated during one minute. For calculating the power of magnetron radiation, the following formula was used. 


$$
P=\frac{C_{p} \cdot m \cdot \Delta T}{t_{h}},
$$

where $C_{p}$ - specific heat of water $\left(4180 \mathrm{~J} /{ }^{\circ} \mathbf{C}\right) ; m$ - water mass $(\mathrm{kg}) ; t_{h}$ - time of water heating $(\mathrm{s})$; $\Delta T$ - difference between initial and final water temperatures $\left({ }^{\circ} \mathbf{C}\right)$.

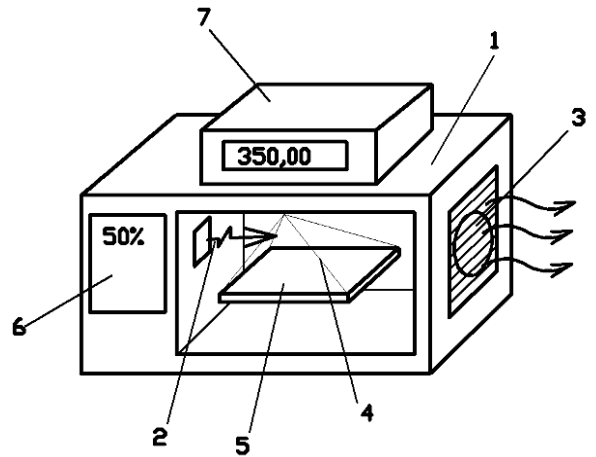

Fig. 1. Scheme of experimental stand for studying the drying process of the immovable wheat layer in the MW field

Two series of experiments with wheat seeds were conducted on the stand. During the first series of experiments the thickness of the wheat layer changed, in the second one the radiation power in the chamber changed.

For studying the moisture removal process at filter-microwave (FMW) drying, the stand was developed (Fig. 2).

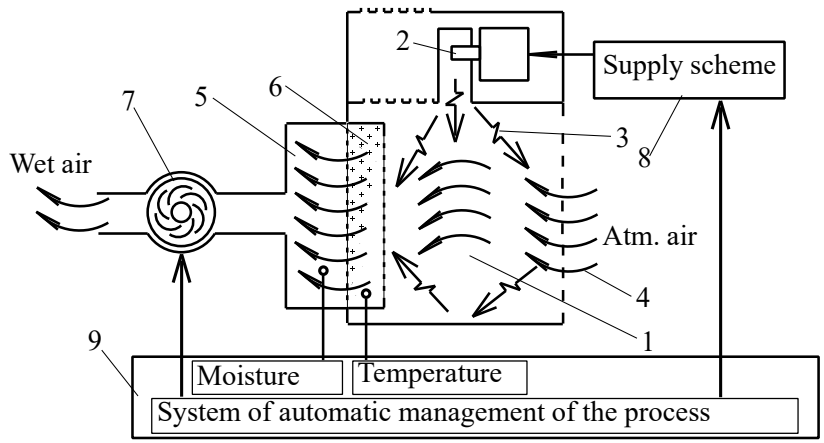

Fig. 2. Scheme of the stand for studying the combined MWF drying method: 1 - microwave chamber, 2 - MW radiator, 3 - Mw radiation, 4 - air flow, 5 - air chamber, 6 - cartridge with the wet material, 7 - ventilator, 8 - supplying system of magnetron, 9 - System of automatic management of the stand

The stand consists of MW chamber 1, with cartridge with the wet material 6. A flow of atmospheric air is blown through the material layer in the cartridge by ventilator 7. Parameters of the moisture removal process are controlled by direct measuring of the cartridge mass and material moisture before and after processing.

The course of the moisture removal process is controlled by indirect parameters - moisture and temperature of the air flow, passed through the cartridge and temperature of the wet material in it.

There was studied a dependence of drying process parameters on a chamber load and, correspondingly, on an energy supply value. The modeling of load changes was realized by choosing three sizes of the cartridge. The material specific load in it was $0.06,0.08$ and $0,085 \mathrm{~kg} / \mathrm{m}^{2}$. The power of MW radiation was $560 \mathrm{~W}$. The MW radiation effect duration was $20 \mathrm{~s}$, blow $-15 \mathrm{~s}$. The air speed at the entrance in the cartridge was $3 \mathrm{~m} / \mathrm{s}$. The cartridge was weighted at laboratory scales each 4 minutes. 
The managing principle of combined drying in this case was in the successive, standardized in time periodical effect on a test sample (wet material layer in the cartridge) by MW radiation and blow of the layer by a flow of atmospheric air.

Such managing method models the successive heating of the layer by MW radiation at passing drying chambers and intensive blow of the layer at passing filter drying zones.

For realizing the algorithm of management and fixation of measuring results of control parameters of the process, there was developed a system of automatic management of the set. A screen of the human-machine interface of the managing program is presented on Fig. 3 .
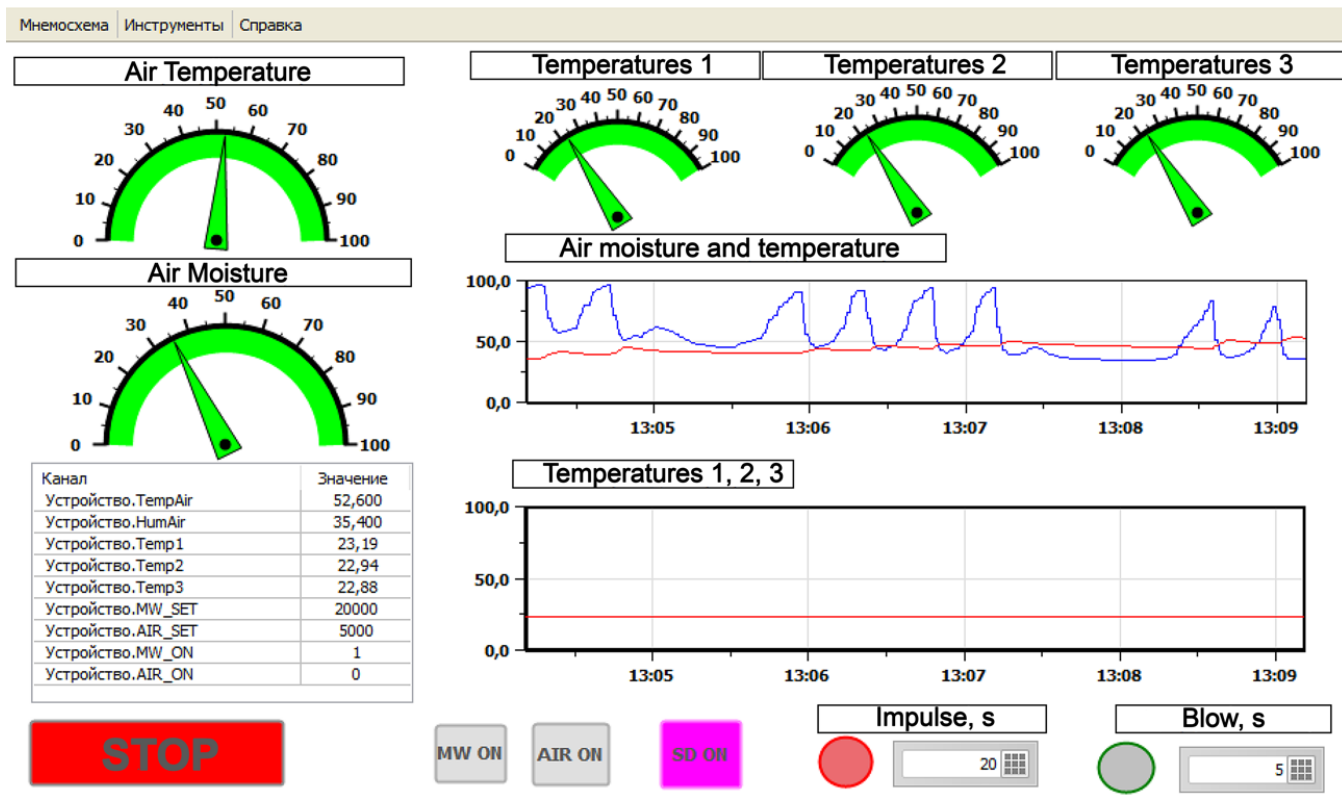

Fig. 3. Screen of the human-machine interface of the managing program

Important parameters of the process are the duration of sample processing by MW radiation and air blow. At the conducted study there were determined main dependencies between the amount of supplied energy and moisture removal intensity.

\section{Results}

As a result of the conducted study, there were determined dependencies of the speed of seed layer dehydration on the radiation power and load value in the microwave heating chamber.

The first group of experiments, conducted on the stand, presented on Fig. 1, allowed to determine a dependence of the speed dehydration on the product mass in the microwave heating chamber.

Graphs of changes of the moisture content of the seed layer at its heating by the microwave field at different power values of microwave radiation and different specific loads are constructed by the obtained data, Fig. 4, 5 .

The graphs of the temperature curves of the seeds layer in the process of heating by the MW field at the given loads and different radiation power values in the heating chamber are presented on Fig. 5.

The thermograms (Fig. 5) demonstrate that the seed layer temperature essentially exceeds technologically permitted temperature values at fodder seed drying $\left(50-60{ }^{\circ} \mathrm{C}\right)$. Such regimes were chosen for widening the base of experimental data, determining stand possibilities.

The dependence of the drying speed on the radiation power in the chamber is obtained by generalizing the experimental results, Fig. 6. 


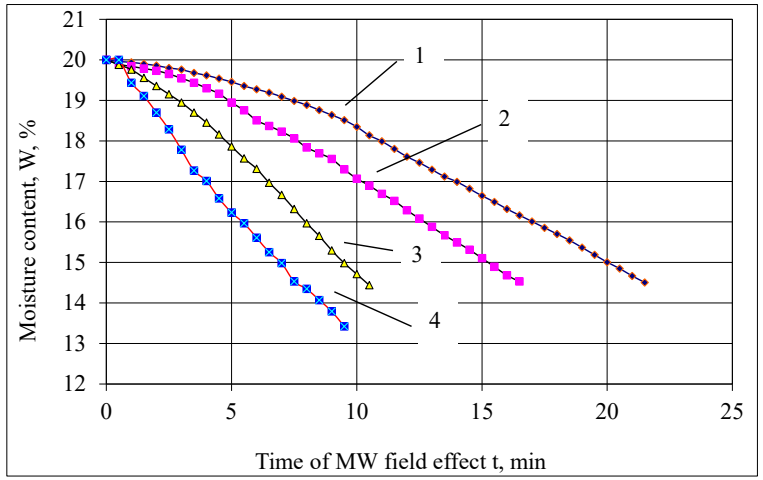

Fig. 4. Change of the moisture content of the seed layer at $N=240 \mathrm{~W}$, load:

$1-5.26 \mathrm{~kg} / \mathrm{m}^{2} ; 2-3.95 \mathrm{~kg} / \mathrm{m}^{2} ; 3-2.63 \mathrm{~kg} / \mathrm{m}^{2} ; 4-1.32 \mathrm{~kg} / \mathrm{m}^{2}$

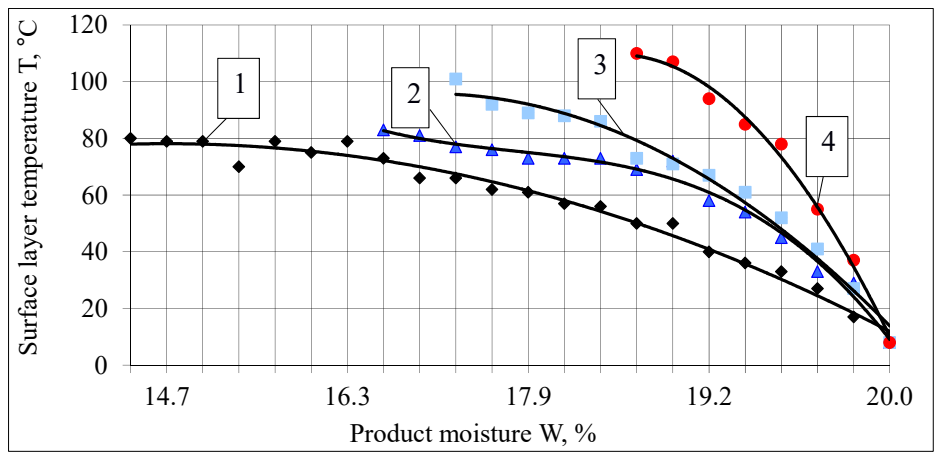

Fig. 5. Thermograms of the seed layer at $G=1.32 \mathrm{~kg} / \mathrm{m}^{2}$. Power of the MW radiator: $1-240 \mathrm{~W}, 2-400 \mathrm{~W}, 3-560 \mathrm{~W}, 4-800 \mathrm{~W}$

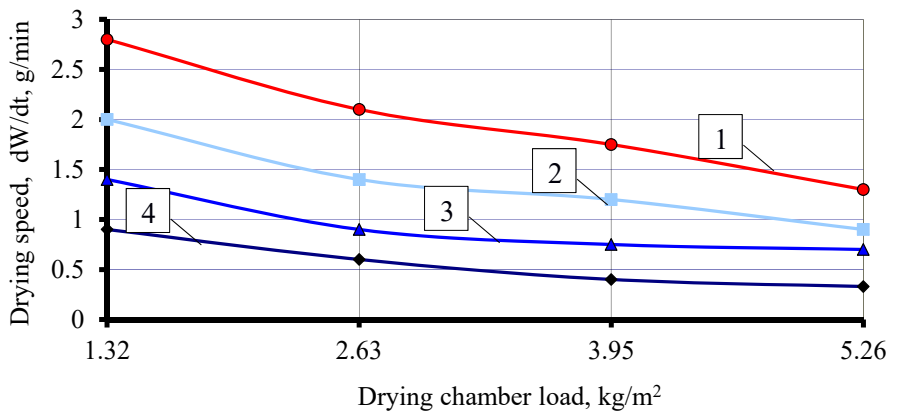

Fig. 6. Dependence of the drying speed on the load value. Power of the MW radiator: $1-800 \mathrm{~W} ; 2-560 \mathrm{~W} ; 3-400 \mathrm{~W} ; 4-240 \mathrm{~W}$

The high temperature regimes result in the drying speed increase.

The change of the MW radiator power in 4 times results in 3 times drying speed increase (Fig. 6).

As a result of the experiments on the stand (Fig. 2), the following data were obtained.

Fig. 7 presents the graphs of changes of the controlled parameters of the process at loading the drying chamber with the layer of wet seeds as $0.08 \mathrm{~kg} / \mathrm{m}^{2}$.

The moisture and temperature of air at the exit from the FMW dryer is of the step type (Fig. 7). It is caused by the fact that the material layer was periodically blown. The air moisture successively increased to $95 \%$ and remained constant that corresponds to the first drying period. Blow practically doesn't influence the air temperature.

The research results allowed to reveal typical dependencies for the combined drying regime. The main ones are presented on Fig. 8-10. 
t, ${ }^{\circ} \mathrm{C}$

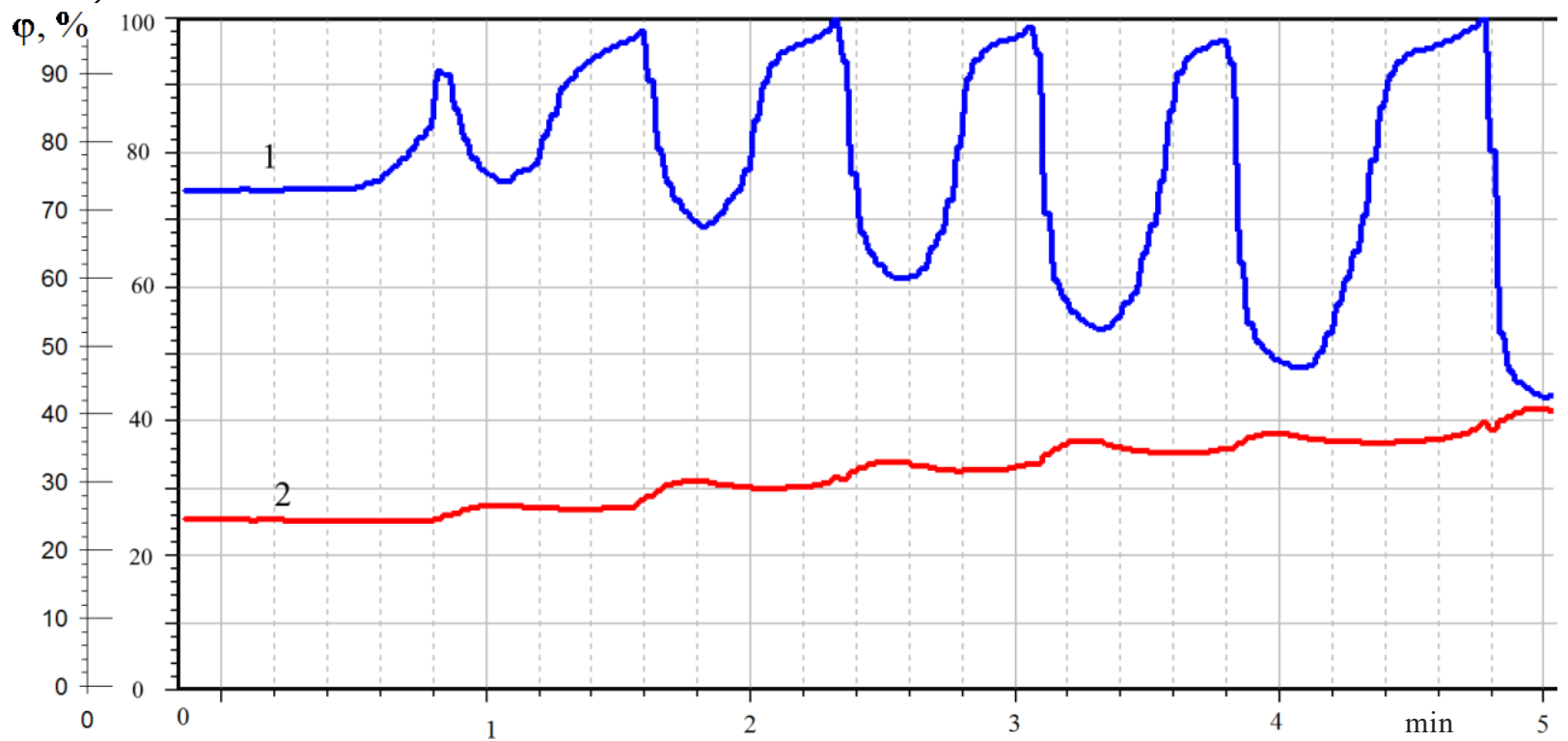

Fig. 7. Changes of the air parameters at the exit from the FMW dryer: 1 - moisture $(\varphi, \%), 2$ - temperature $\left(t,{ }^{\circ} \mathrm{C}\right)$

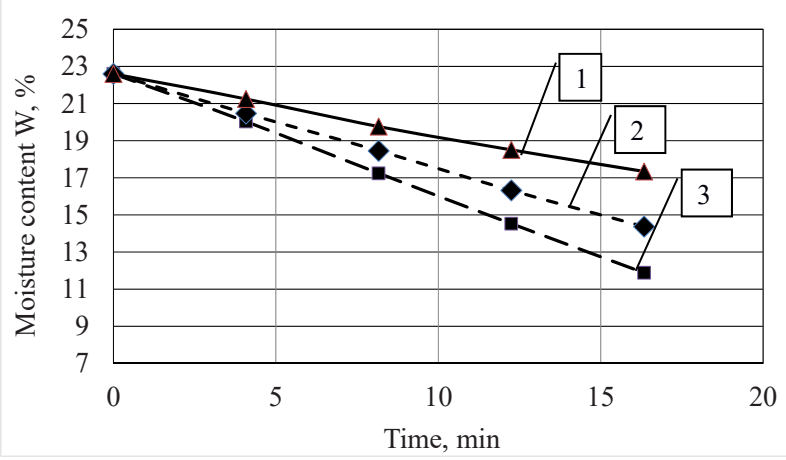

Fig. 8. Change of the moisture content of the seed layer at radiator power $560 \mathrm{~W}$. Specific load:

$$
1-0,085 \mathrm{~kg} / \mathrm{m}^{2} ; 2-0.08 \mathrm{~kg} / \mathrm{m}^{2} ; 3-0.06 \mathrm{~kg} / \mathrm{m}^{2}
$$

Drying takes place at the first period that is testified by the constant drying speed value, Fig. 9. At the first period surface moisture, separated from seeds at the expanse of the MW radiation effect, is removed.

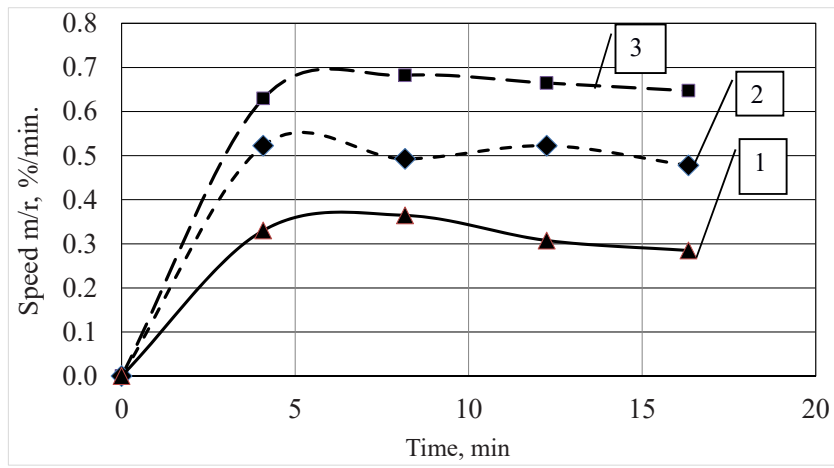

Fig. 9. Dependence of the drying speed on the specific load value: $1-0,085 \mathrm{~kg} / \mathrm{m}^{2} ; 2-0.08 \mathrm{~kg} / \mathrm{m}^{2} ; 3-0.06 \mathrm{~kg} / \mathrm{m}^{2}$ 
The specific load decrease at FMW drying results in the process speed increase up to $0.7 \% / \min$ (Fig. 9).

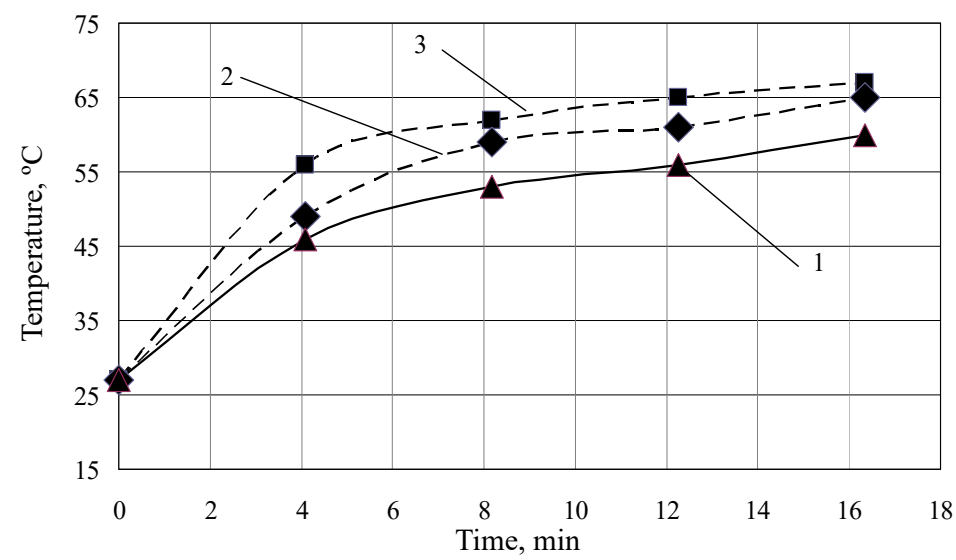

Fig. 10. Thermograms of the seed layer on the specific load value: $1-0,085 \mathrm{~kg} / \mathrm{m}^{2} ; 2-0.08 \mathrm{~kg} / \mathrm{m}^{2} ; 3-0.06 \mathrm{~kg} / \mathrm{m}^{2}$

The drying process in the FMW dryer takes place at the wheat temperatures (curves 1, 2, Fig. 10), correspondent to technological requirements for fodder seeds drying.

Specific energy consumption for MW seed drying was $4 \mathrm{MJ} / \mathrm{kg}$, FMW dryer $-3.8 \mathrm{MJ} / \mathrm{kg}$. It is lower than for correspondent convective dryers. The drying speed in MW dryers changes from 0.5 to $3 \% / \mathrm{min}$ (Fig. 6), in FMW dryers from 0.3 to $0.7 \% / \mathrm{min}$ (Fig. 9). The speed is at the level of standard convective dryers.

\section{Conclusions}

The conducted experiments proves the possibility of intensifying the process of moisture removal in a MW dryer for wheat seeds at the expanse of creating an intensive air flow, normal to the plane of the wet material layer with speeds, typical for filter drying methods (within 3-8 m/s), and parameters, correspondent to the normal atmosphere condition.

The conducted studies allow to recommend producers of the drying equipment the new combined way of FMW drying of seeds with low energy consumption $(3.8 \mathrm{MJ} / \mathrm{kg})$.

The revealed features of heating and drying of wheat seeds are expedient to be used at developing industrial MW and FMW dryers.

The base of experimental data is possible to be used for optimizing and determining effective conditions of MW and FMW drying processes.

A shortcoming for using the results for FMW drying is the absence of a product movement that essentially decreases the stand productivity. It must be also noted, that for realizing the process in the industrial scale, it is necessary to develop the specialized microwave equipment. The experimental studies must be continued for this aim.

\section{References}

[1] Nathakaranakule, A., Paengkanya, S., Soponronnarit, S. (2019). Durian chips drying using combined microwave techniques with step-down microwave power input. Food and Bioproducts Processing, 116, 105-117. doi: https://oi.org/10.1016/ j.fbp.2019.04.010

[2] Peng, J., Yin, X., Jiao, S., Wei, K., Tu, K., Pan, L. (2019). Air jet impingement and hot air-assisted radio frequency hybrid drying of apple slices. LWT, 116, 108517. doi: https://doi.org/10.1016/j.lwt.2019.108517

[3] Zhou, X., Ramaswamy, H., Qu, Y., Xu, R., Wang, S. (2019). Combined radio frequency-vacuum and hot air drying of kiwifruits: Effect on drying uniformity, energy efficiency and product quality. Innovative Food Science \& Emerging Technologies, 56, 102182. doi: https://doi.org/10.1016/j.ifset.2019.102182

[4] Vishwanathan, K. H., Giwari, G. K., Hebbar, H. U. (2013). Infrared assisted dry-blanching and hybrid drying of carrot. Food and Bioproducts Processing, 91 (2), 89-94. doi: https://doi.org/10.1016/j.fbp.2012.11.004 
[5] Onwude, D. I., Hashim, N., Abdan, K., Janius, R., Chen, G. (2019). The effectiveness of combined infrared and hot-air drying strategies for sweet potato. Journal of Food Engineering, 241, 75-87. doi: https://doi.org/10.1016/j.jfoodeng.2018.08.008

[6] Kroehnke, J., Szadzińska, J., Stasiak, M., Radziejewska-Kubzdela, E., Biegańska-Marecik, R., Musielak, G. (2018). Ultrasound- and microwave-assisted convective drying of carrots - Process kinetics and product's quality analysis. Ultrasonics Sonochemistry, 48, 249-258. doi: https://doi.org/10.1016/j.ultsonch.2018.05.040

[7] Onwude, D. I., Hashim, N., Abdan, K., Janius, R., Chen, G. (2019). Experimental studies and mathematical simulation of intermittent infrared and convective drying of sweet potato (Ipomoea batatas L.). Food and Bioproducts Processing, 114, $163-174$. doi: https://doi.org/10.1016/j.fbp.2018.12.006

[8] Łechtańska, J. M., Szadzińska, J., Kowalski, S. J. (2015). Microwave- and infrared-assisted convective drying of green pepper: Quality and energy considerations. Chemical Engineering and Processing: Process Intensification, 98, 155-164. doi: https:// doi.org/10.1016/j.cep.2015.10.001

[9] Kowalski, S. J., Rajewska, K. (2009). Effectiveness of hybrid drying. Chemical Engineering and Processing: Process Intensification, 48 (8), 1302-1309. doi: https://doi.org/10.1016/j.cep.2009.05.009

[10] Symak, D. M., Atamaniuk, V. M. (2011) Heat and mass transfer during filtration drying of disperse materials occurring in the first period. Eastern-European Journal of Enterprise Technologies, 1 (9 (49)), 23-26. Available at: http://journals.uran.ua/eejet/ article/view/2440/2241

[11] Kindzera, D. P., Atamaniuk, V. M., Mykychak, B. M. (2014). Internal diffusion transfer of moisture during birch veneer filtration drying. Eastern-European Journal of Enterprise Technologies, 2 (11 (68)), 48-52. Available at: http://journals.uran.ua/ eejet/article/view/23508/21052

[12] Atamaniuk, V. M., Kindzera, D. P., Huzova, I. O. (2010). Heat exchange in the stationary layer of dry finely divided capillary-porous material. Eastern-European Journal of Enterprise Technologies, 3 (7 (45)), 21-25. Available at: http://journals. uran.ua/eejet/article/view/2858/2661

[13] Hammouda, I., Mihoubi, D. (2014). Comparative numerical study of kaolin clay with three drying methods: Convective, convective-microwave and convective infrared modes. Energy Conversion and Management, 87, 832-839. doi: https:/doi.org/ 10.1016/j.enconman.2014.07.085

[14] Li, Y., Zhang, T., Wu, C., Zhang, C. (2014). Intermittent microwave drying of wheat. Journal of Experimental Biology and Agricultural Sciences, 2 (1), 32-36. Available at: http://www.jebas.org/wp-content/uploads/2014/09/Zhang-et-al-JEBAS1.pdf

[15] Volgusheva, N., Altman, E., Boshkova, I., Titlov, A., Boshkov, L. (2017). Study into effects of a microwave field on the plant tissue. Eastern-European Journal of Enterprise Technologies, 6 (8 (90)), 47-54. doi: https://doi.org/10.15587/17294061.2017.115118

[16] Potapov, V. A., Yakushenko, E. N., Gritsenko, O. Yu. (2015). Fil'tratsionnaya sushka pri povyshennom davlenii. Naukovi pratsi ONAKhT, 2 (47), 134-137.

Received date 20.07.2019

Accepted date 10.09.2019

Published date 17.09.2019
(C) The Author(s) 2019

This is an open access article under the CC BY license (http://creativecommons.org/licenses/by/4.0). 